FACTA UNIVERSITATIS

Series: Economics and Organization Vol. 16, $\mathrm{N}^{\mathrm{o}} 1$, 2019, pp. 13 - 30

https://doi.org/10.22190/FUEO1901013K

Original Scientific Paper

\title{
THE IMPORTANCE OF SCIENCE FOR IMPROVING COMPETITIVENESS OF NATIONAL ECONOMY
}

\author{
UDC 330.341.1:001.892
}

\author{
Miloš Krstić ${ }^{1}$, Bojan Krstić ${ }^{2}$, Ratomir Antonović ${ }^{3}$ \\ ${ }^{1}$ University of Niš, Faculty of Science and Mathematics, Serbia \\ ${ }^{2}$ University of Nišs, Faculty of Economics, Serbia \\ ${ }^{3}$ Faculty of Law, Security and Management "Konstantin Veliki”, Niš, Serbia
}

\begin{abstract}
The aim of the paper is to examine the interdependence of the selected indicators from the Global Competitiveness Report and the Innovation pillar, which is used as a proxy indicator of the science competitiveness. This relationship is analyzed within the sample of 9 countries. The analysis uses available information sources in WEFs annual reports. The key contribution of this paper consists in providing clearer into factors competitiveness in the analyzed countries and pointing out the priority actions for the authorities to improve and increase the competitiveness level of science, and its contribution to the national economy competitiveness level. The research results can serve policy makers in shaping strategies and policies for the competitiveness improvement and the future of economic development in the analyzed countries.
\end{abstract}

Key words: competitiveness, science, young talents, highly skilled professionals, innovation

JEL Classification: I23, O15

\section{INTRODUCTION}

Competitiveness is a multidimensional concept that includes a multitude of different aspects and factors that determine it. Observed from the microeconomic aspect, competitiveness is the ability of the company to continuously meet the needs of consumers with high quality products and services that will enable it to achieve long and stable profit. Observed from the macroeconomic aspect, competitiveness is not uniquely determined. In the attempt to answer the question: What is national competitiveness? Porter also points to various understandings of

Received December 14, 2018 / Accepted February 28, 2019

Corresponding author: Miloš Krstić

Faculty of Science and Mathematics, University of Niš, Višegradska 33, 18000 Niš, Serbia

E-mail: krsticmilo3@gmail.com 
this term: "There are attitudes that consider competitiveness as a macroeconomic phenomenon, which is determined by the level of interest rates and budget deficit, as well as the movement of the exchange rate, but also the structure and price of the labor force. Attitudes that connect competitiveness with natural resources, but also those who consider that competitiveness is determined by macroeconomic policies for protecting domestic production, promoting exports, subsidizing, etc.“(Porter, 2004, p. 76).

Without diminishing the importance of the aforementioned positions, Porter points out that the prosperity of a nation is not inherited, but created by the strategic choices. It links national competitiveness with productivity on the macro level and believes that the standard of living of citizens can only be improved if enterprises are able to achieve a high level of efficiency (productivity, profitability) and increase it over time. Thus, the efficiency of a country is ultimately determined by the efficiency of enterprises operating in that country (Porter, 2004, p. 31).

For comprehensive overview of the competitiveness of a national economy, it is necessary to properly understand the role of the science sector in improving the competitiveness of national economy. In this sense, we will begin by establishing the basic characteristics of the science sector in developing countries, which are comparable, according to their structural and economic-historical characteristics and the trajectory of economic dynamics. Then, statistical and analytical data on scientists and their professional career will be presented. In the last part of this work, special attention will be devoted to determination of science indicators that represent the "lack" of the country, but that are important for improving the competitiveness of the economy. For this purpose, the methodology of the World Economic Forum for measuring the competitiveness of a country will be used.

The key contribution of this paper is reflected in clearer understanding of the role and significance of the indicators of the competitiveness of science in improving the competitiveness of the national economy and providing recommendations in the form of desirable activities of the competent state organs in order to maintain the existing competitive advantages and minimize weakness.

\section{BASIC CHARACTERISTICS OF THE SCIENCE SECTOR IN DEVElOPING COUNTRIES}

Science is one of the most perfect forms of accumulation and systemization of knowledge and experience. Science is a system for diffusion, sharing and transfer of knowledge. It develops general and specific methodologies and methods of research. Mastering these methods and methodologies substantially rationalizes the researcher's strength, "releases" researcher from many unproductive jobs, and shortens the path towards discovering the new one.

There is growing evidence that science contributes significantly to the overall power of the state, economic prosperity and growth of the living standards (Medianik, 2017). Without modern science it is impossible to build innovative economy and respond to new challenges and the international standards.

In developing countries, where science is not developed, this sector is characterized by: 1) rigid scientists' payments scheme with low basic wages, 2) numerous formal criteria for the evolution of productivity of scientists that, as a rule, are non-transparently 
implemented; 3) "poor" academic mobility, and 4) social networks and informal contacts that play a major role in the career development of researchers or during acquiring of scientific titles (Gershman \& Kuznetsova, 2013).

In many countries, the development of science takes place under conditions of visible contradictions between the society's expectations regarding the quality of research results, on one hand, and the real contribution of science to the development of economy and increase in the well-being of citizens, on the other. The science sector faces problems such as: low reputation and influence of the scientific profession, relatively low wages, obsolete infrastructure and equipment, the high average age of researchers and the "brain drain" (Gokhberg et al., 2011).

Most research and development organizations in developing countries are state owned. These organizations spend a large part of budgetary resources, have poor performance, and are not sufficiently competitive in market conditions. These organizations are under great pressure to adapt to the fast-changing dynamics of innovation, including increased competition for key resources (primarily for highly skilled staff) and changes in public procurement priorities in the area of science, technology and innovation. Not surprisingly, state-owned scientific organizations are the key subject of numerous reforms, although the size of the sector indicates that the implementation of such reforms is not a quick and painless process.

Many countries emphasize providing decent wages to researchers with strict requirements regarding employment in the science sector and acquiring scientific titles (Altbach et al., 2012). However, in countries that do not have sufficiently developed science, there are still low basic wages and minimal differences between payment grades. This situation does not contribute to attracting young researchers and retaining good staff and does not allow the increase of international competitiveness of domestic researches. Countries that do not have sufficiently developed science need to focus, first of all, on the increase of the basic wages, which requires the increase of resources from the budget for science (Gershman \& Kuznetsova, 2013). For most developing countries, this goal is unattainable, given the available resources. The solution to this problem is to provide additional resources from non-governmental funds.

On the whole, the introduction of new mechanisms for researchers' payment in research organizations means that researchers can earn wages that are comparable to the salaries in the business sector. As a result, many scientists, including young researchers, will be able to buy an apartment by raising loans form banks. Nevertheless, increasing researchers' wages, without solving other problems like the increasing productivity or the reduction of unreasonable demands for salary increasement, would be risky. The new mechanism for paying scientific work would be largely meaningless without taking into account these important factors. In addition, the increase in researchers' wages can lead to the influx of workers from other sectors into the science sector. However, such inflow does not automatically improve the situation in the science sector. On the contrary, the quality of research and development can be deteriorated by the arrival of incompetent people who are mostly motivated by money (Gokhberg et al., 2011). Gershman and Kuznetsova point to the importance of linking wages of researchers with the productivity of their work. They indicate that more adequate incentives (wages) will be effective only if other measures are applied, like: provision of modern equipment, improvement of working conditions, etc. (Gershman \& Kuznetsova, 2013). 
It should be noted that the results of the researches of the science sector in the countries of Central Europe indicate that the scientific system in these countries was strongly shaken in the 1990s. The scientific environment was faced with the difficulties caused by the decapitalization of physical infrastructure and the increase in the average age of researchers. The decapitalization of physical infrastructure is considered one of the most important structural problems in the national scientific systems of the countries of Central Europe, while the increase in the average age of scientific workers caused decrease in wages, which led to internal and external "brain drain" (Bulgarian Ministry of Education and Science, 2002). After all, policies in the field of science were not always properly organized and that had a negative impact on their quality. This situation was the responsibility of several ministries that had easily taken into account the poor state of the industry and bad policies in the field of science and technological development.

The structure of working hours of researchers in economically underdeveloped countries depends on the level of wages (that is compensated by consulting, tutoring and others), as well as by insufficient equipment for work and the absence of scientific information. Because they have quality equipment and reliable information, researchers in developed countries may have advantage in terms of time over researchers in countries where science is not developed enough. Therefore, the improvement of technical infrastructure and strengthening of the base of scientific information should, in some way, enable the partial leveling (decreasing) of the differences in the competitiveness between researchers in countries with developed science and researchers in countries with in sufficiently developed science.

As already pointed out, measures to increase the productivity of researchers can produce the expected effects only in combination with complex institutional and legal measures that are often not directly related to science. Institutional and financial aspects of the organization of science are the subject of "fierce" discussion in many countries that do not have developed science. According to Gershman and Kuznetsova, in Russia, 90\% of research teams in some areas of science are inefficient, and many of them have no chance of improving their productivity. For example, in the field of biomedicine, only 450 of nearly 4000 laboratories are productive (Gershman \& Kuznetsova, 2013). Significantly increasing wages without systemic reforms in the science sector can be "disastrous". This would not help to solve the problem of "dead wood" (unproductive researchers). Increasing wages without wider system changes means that non-productive researchers should be fed by increased wages. Institutional reforms must follow the radical modernization of material and technical infrastructure, including premises and equipment. The practice of "sticking plaster" with investments from the budget in several priority areas is not adequate for solving the accumulated problems.

The problem of inadequate information of researchers about the state policy in the field of science and technology has several aspects (Gokhberg et al., 2011). The low level of information among researchers reflects the low quality of policies that should be modified based on continuous feedback and interaction with the scientific community and specific target groups. Information about state policy in the field of science and technology is important for stakeholders, scientific institutes and universities that strive to increase efficiency (productivity) within existing limitations.

In general, scientists in developing countries are characterized by passivity, even regarding issues that directly affect their interests. According to the research of Gershman and Kuznetsova, in Russia $16 \%$ of managers of scientific institutes and universities and 
$36 \%$ of researchers of scientific institutes and universities obtained about the changes to remuneration mechanisms during the same research. This fact seems quite surprising, given the degree of "sharp debates" and significant media coverage. It showed that in Russia scientists with universities were better informed in relation to researchers of scientific institutes and universities (Gershman \& Kuznetsova, 2013).

\section{SCIENTISTS AND THEIR CAREER}

Scientists represent a relatively small proportion of the total population, but their significance is quite high (OECD, 2010). Given that they have specialized education and their contribution to science, one should expect that scientists will play an important role in knowledge economy and improve competitiveness of a country. Information on the career of scientists and their contribution to science, innovation and economics are important not only for policy makers and state institutions that finance their training and integration into scientific and innovative systems, but also for employers who are interested in the competencies of scientists. Unfortunately, the information on these experts is scarce due to the fact that standard statistical sources are too small (Auriol et al, 2013).

Significant changes have occurred in the structure of the labor market and in the organization of research activities that have contributed to the expansion of the trajectory of the career of the persons with the highest academic title the doctor of philosophy. In the run-up to the economic and financial crisis in 2008, doctors of science often changed jobs and did not intend to preserve jobs in the higher education sector. With the increase in the number of doctorate holders, some asked the question: How to successfully exploit this potential in the innovation system?

In the countries whose data are available, at least $50 \%$ of the persons with the title 'doctor of science' work as researchers. In Portugal and Poland, more than $80 \%$ of those with the highest academic title work as researchers, while the share of these experts is lowest (close to 60\%) in Turkey, Spain and Romania (Figure 1). Doctorate holders in the natural sciences and engineering are the most frequently employed as researchers, except in Portugal and Poland where there are no obvious differences across fields.

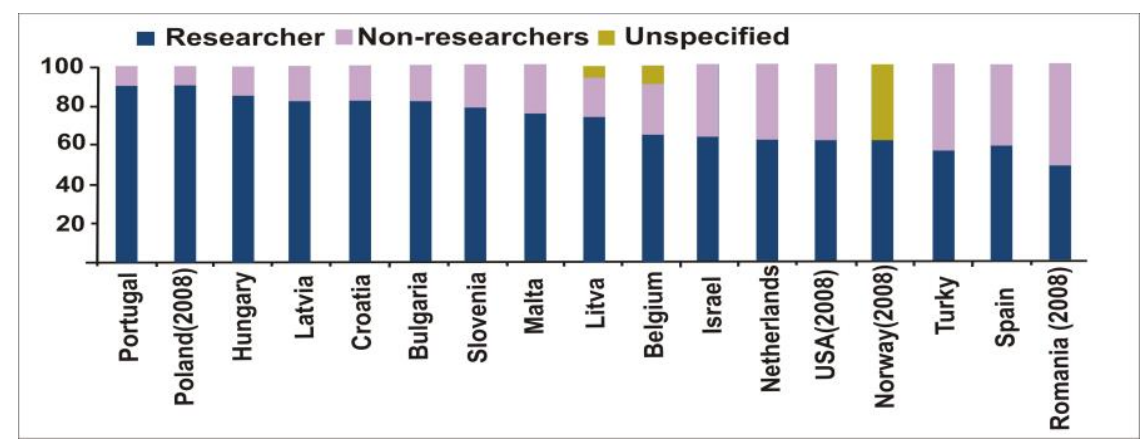

Fig. 1 Distribution of persons with the highest academic title doctor of philosophy by professions Source: Auriol, L., Misu, M., \& Freeman R. (2013). Careers of Doctorate Holders: Analysis of Labour Market and Mobility Indicators. Paris: OECD Publishing. 
The main sector of employment for researchers is higher education (Figure 2). The largest share of doctors of philosophy who work as researchers in the higher education sector and the first place on the list of countries whose data are available was recorded by Poland, while the lowest share was recorded by the Netherlands. In Belgium, the United States and the Netherlands, the business sector also employs a large number of researchers.

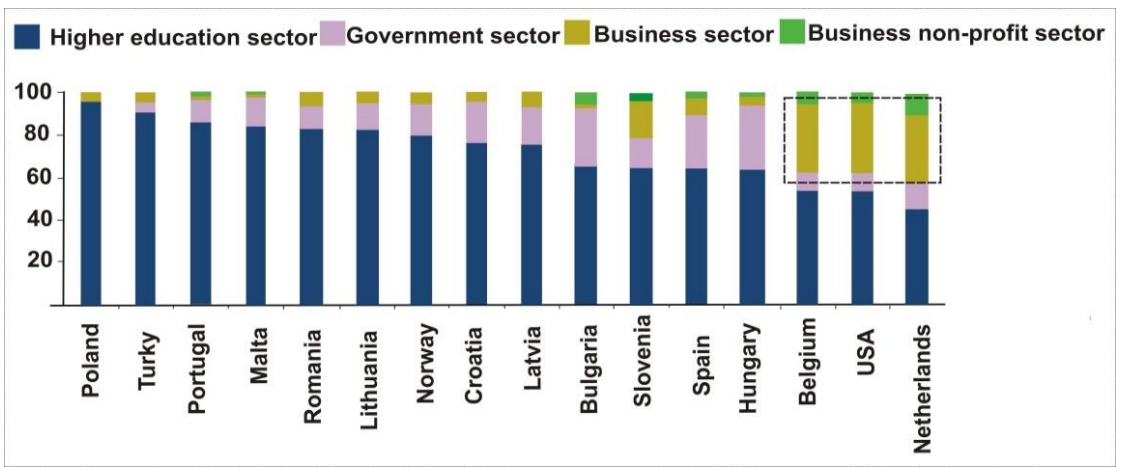

Fig. 2 Distribution of researchers in the sectors

Source: Auriol, L., Misu, M., \& Freeman R. (2013). Careers of Doctorate Holders: Analysis of Labour Market and Mobility Indicators. Paris: OECD Publishing.

Given that they traditionally choose the higher education sector, a large proportion of doctorate holders in the business sector point to high demand for individuals with specialized knowledge outside the higher education sector and/or less employment opportunities in the higher education sector.

If we observe the availability of scientists and engineers and company spending on $R \& D$, the business sector appears as the main $R \& D$ performer. The efficiency of the transfer of knowledge of researchers into the industry and the cooperation or degree of interconnection between universities and industry in order to develop innovation activities depends on how effectively the competences of scientific staff are used.

During the previous round of the $\mathrm{CDH}$ project ${ }^{1}$, it was determined that the business sector primarily employs researchers dealing with natural and technical sciences (Auriol, 2010). Figure 3 shows that the business sector employs natural scientists from natural and technical sciences mostly in countries like Belgium, the Netherlands and the United States. About half of the total number of researchers dealing with natural and technical sciences is employed in the business sector in these countries. The business sector of these countries is able to "strengthen" its intellectual potential to some extent by employing experts with the title 'doctor of science' in the field of social sciences and humanities. However, their inflow does not exceed 10\% (Figure 3). Many researchers in countries, whose data are available, work in the business non-profit sector. Although in

\footnotetext{
${ }^{1}$ The $\mathrm{CDH}$ project is a recent initiative launched by the Organization for Economic Cooperation and Development (OECD), the UNESCO Institute for Statistics and Eurostat. These organizations have created databases of doctors of philosophy in different countries in order to obtain statistically robust (reliable or valid) data on scientists and their professional career.
} 
the business sector there is a great demand for researchers in the field of natural and technical sciences, their supply is significantly low in Poland, Portugal and Turkey.

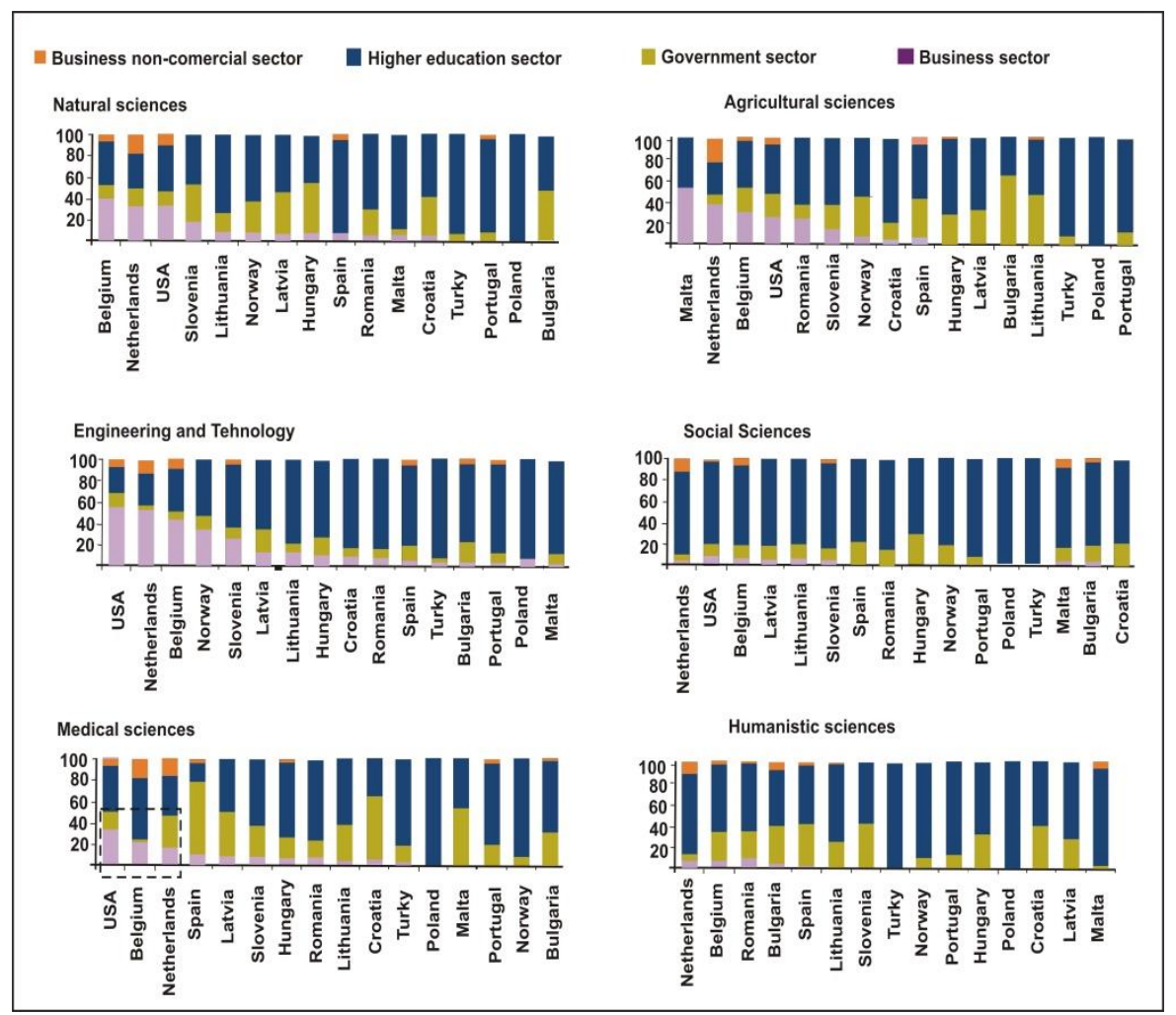

Fig 3 Distribution of researchers by fields of sciences and sectors Source: Auriol, L., Misu, M., \& Freeman R. (2013). Careers of Doctorate Holders: Analysis of Labour Market and Mobility Indicators. Paris: OECD Publishing.

The main goal of many countries is the employment of young and creative professionals in the science sector. Still, young people are losing interest in science. In the United States the main reasons for this are: the long time it takes to obtain an advanced degree, the additional unstable postdoctoral training before securing a tenured position, the lowering researchers' lifetime earnings expectations and finding a balance between family decisions and research career. Female researchers are pariculary bz the latter. The situation is similar in other countries (OECD, 2008).

Starting from these cognitions, we will discuss the analysis of the indicators of country's competitiveness in the field of science in the second part of the paper. The goal is to examine their role in improving the competitiveness of the science sector. 


\section{RESEARCH HYPOTHESES AND METHODOLOGY}

World Economic Forum (WEF) analyzes a number of factors that affect the country's competitiveness in many segments of life. These factors are classified in 12 pillars of competitiveness. Each of the pillars consists of a large number of sub indicators.

In order to improve the competitiveness and innovation of science, in our opinion, the following sub indicators are of great importance: hiring and firing practices, country capacity to retain talent, country capacity to attract talent, availability of the latest technology and foreign direct investment and technology transfer.

The latest pillar of the WEF titled Innovation can be considered a composite index of competitiveness of science that is formed as the weighted average of the following sub indicators: 1) capacity for innovation, 2) quality of scientific research institutions, 3) company spending on $R \& D, 4)$ university-industry collaboration in $R \& D, 5)$ government procurement of advanced technology products, 6) availability of scientists and engineers, 7) PCT patents applications/million pop.

The aim of this research is to examine the relationship between the 12th pillar of the WEF Innovation or "Global innovation index", on one hand, and the above-mentioned factors of the competitiveness of science, on the other. In line with the research objective, the following hypotheses will be tested:

H1: Linear combinations of the observed indicators of competitiveness of science that are in the deepest connection with global innovation index are:

1) foreign direct investment and technology transfer/availability of the latest technology,

2) hiring and firing practices/availability of the latest technologies,

3) availability of the latest technologies/country capacity to retain talent, and

4) country capacity to attract talent/availability of the latest technologies.

$\mathrm{H}$ 2: The individual indicators of the competitiveness of science that most affect the global innovation index in the analyzed countries are: the country capacity to retain talent, the country capacity to attract talent, the availability of the latest technologies and the foreign direct investment and technology transfer.

The sample covered 9 countries. The criteria for selecting countries in the sample are: 1) similar characteristics and the path of development of science and 2) the degree of social development. In the sample, we considered countries that faced the inherited institutional structure of the socialistic scientific system and the process of transition to the capitalist economy at the end of the last century. These are countries that had insufficiently developed financing mechanisms of science, a high degree of bureaucratization, fragmentation and centralization of science that did not correspond to the market economy model, universities with weak links to science and military-industrial complex that limited the transfer of technology to the civil sector (Schuch, 2014). The level of social development is expressed by gross domestic product per capita per purchasing power parity in current dollars (GDP per capita, PPP (current \$)) in 2017 (Table 1). The data on per capita GDP per capita purchasing power parity are found in the World Bank's World Development Indicators. They are downloaded from the website of this institution https://data.worldbank.org/. 
Table 1 Gross domestic product per capita PPP (in current US dollars) of selected countries in the sample

\begin{tabular}{lc}
\hline Countries & $\begin{array}{c}\text { GDP per capita, PPP } \\
\text { (current \$) in 2017 }\end{array}$ \\
\hline Bulgaria & $20,329.3$ \\
Croatia & $25,264.4$ \\
Hungary & $28,107.9$ \\
Latvia & $27,598.3$ \\
Montenegro & $18,765.1$ \\
Poland & $29,026.2$ \\
Romania & $25,840.8$ \\
Serbia & $15,090.0$ \\
Lithuania & $32,095.5$ \\
\hline
\end{tabular}

Source: https://data.worldbank.org/indicator/NY.GDP.PCAP.PP.CD? end $=2014 \&$ start $=1990 \&$ view $=$ chart

The analysis used the method of multiple linear regression. The Global Competitiveness Report and World Bank's World Development Indicators are the informational basis for this research. The analysis used programs for processing and presentation of statistical data: SPSS and MatLab.

\subsection{Results of research and discussion}

3.1.1. Analysis of selected countries according to the Innovation pillar

According to the report of the WEF for 2017/2018, Serbia is ranked $95^{\text {th }}$ in terms of the value of the Innovation pillar. Compared to 2013/2014, the value of the pillar Innovation came up by 0.2 , which led to the positive shift of Serbia by 17 positions (from the $112^{\text {th }}$ place to the $95^{\text {th }}$ place on the WEF list). Table 2 shows the ranks and results of the Innovation pillar for Serbia from 2013/2014 to 2017/2018.

Table 2 Republic of Serbia -The Innovation pillar, 2013/2014-2017/2018

\begin{tabular}{lcccc}
\hline \multirow{2}{*}{ Year } & \multicolumn{2}{c}{ Innovation } & \multicolumn{2}{c}{ Change } \\
\cline { 2 - 5 } & Result & Rank & Result & Rank \\
\hline $2013 / 2014$ & 2.9 & 112 & - & - \\
$2014 / 2015$ & 2.9 & 108 & 0 & $\uparrow 4$ \\
$2015 / 2016$ & 2.9 & 113 & 0 & $\downarrow 5$ \\
$2016 / 2017$ & 3.0 & 108 & $\uparrow 0.1$ & $\uparrow 5$ \\
$2017 / 2018$ & 3.1 & 95 & $\uparrow 0.1$ & $\uparrow 7$ \\
\hline Total & - & - & $\uparrow 0.2$ & $\uparrow 12$ \\
\hline Source: WEF, The Global Competitiveness Reports 2013/2014, 2014/2015, 2015/2016, \\
\multicolumn{5}{c}{ 2016/2017 and 2017/2018 }
\end{tabular}

Also, the next diagram illustrates the moving of the Innovation pillar for Serbia in the period from 2013/2014 to 2017/2018. The diagram was obtained from the data from Table 2 . 
The red line in Figure 4 shows the movement of the results of the Innovation pillar, while the blue line shows the movement of the ranks of this pillar in the period from 2013/2014 to 2017/2018. Based on Figure 4, we see that Serbia achieved the greatest "positive shift" in 2017/2018.
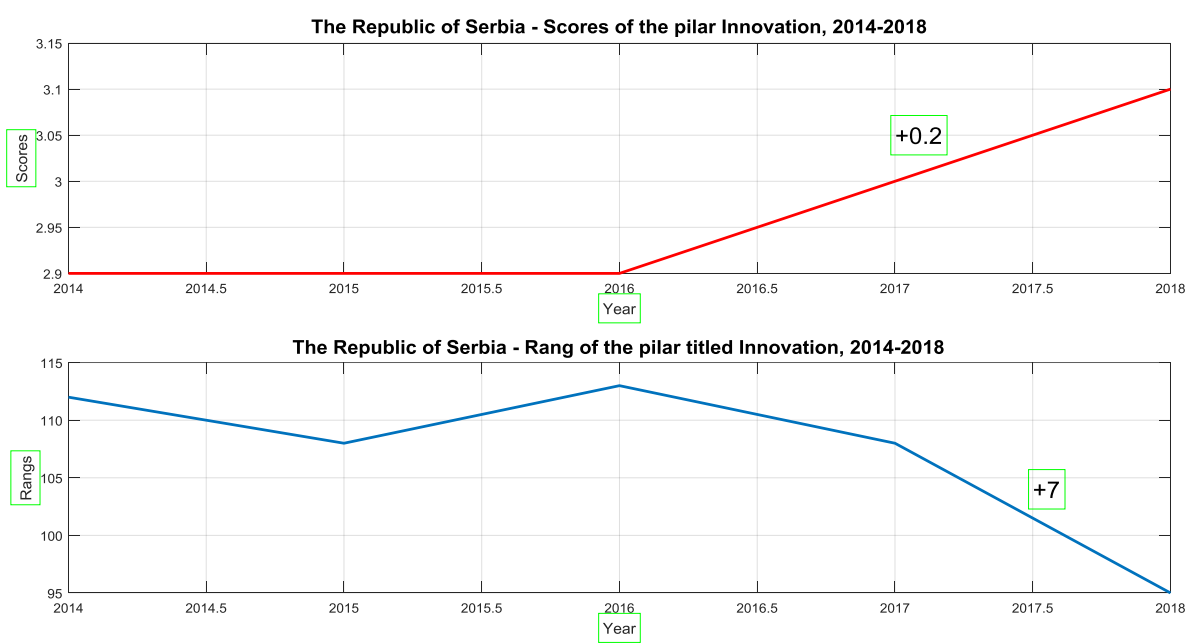

Fig 4 The Republic of Serbia - Scores and Rang of Innovation pillar, from 2014 to 2018 Source: The authors in Matlab

The following table illustrates the ranking of selected countries in the sample according to the rank and the value of the Innovation pillar (Table 3). This comparison provides a more precise picture of the competitiveness of science in the observed countries (Krstić \& Stanišić, 2014, 93).

Table 3 The Innovation pillar - ranking of analyzed countries

\begin{tabular}{|c|c|c|c|c|c|c|c|}
\hline \multirow[t]{2}{*}{ Country } & \multicolumn{2}{|c|}{$\begin{array}{l}\text { Innovation } \\
2013 / 2014- \\
\text { world list of } \\
\text { countries }\end{array}$} & \multirow[t]{2}{*}{$\begin{array}{c}\text { Rank within the } \\
\text { analyzed } \\
\text { countries in } \\
2013 / 2014\end{array}$} & \multicolumn{2}{|c|}{$\begin{array}{l}\text { Innovation } \\
2017 / 2018- \\
\text { world list of } \\
\text { countries }\end{array}$} & \multirow[t]{2}{*}{$\begin{array}{l}\text { Rank within } \\
\text { the analyzed } \\
\text { countries in } \\
2017 / 2018\end{array}$} & \multirow[t]{2}{*}{$\begin{array}{l}\text { Change } \\
\text { of score }\end{array}$} \\
\hline & Rank & Score & & Rank & Score & & \\
\hline Bulgaria & 105 & 3.0 & 8 & 68 & 3.3 & 3 & +0.3 \\
\hline Croatia & 79 & 3.1 & 6 & 106 & 2.9 & 9 & -0.2 \\
\hline Hungary & 71 & 3.6 & 5 & 79 & 3.5 & 5 & -0.1 \\
\hline Latvia & 70 & 3.2 & 4 & 68 & 3.6 & 4 & +0.4 \\
\hline Montenegro & 54 & 3.4 & 2 & 91 & 3.2 & 6 & -0.2 \\
\hline Poland & 65 & 3.2 & 3 & 59 & 3.4 & 2 & +0.2 \\
\hline Romania & 97 & 3.0 & 7 & 96 & 3.1 & 8 & +0.1 \\
\hline Serbia & 112 & 2.9 & 9 & 95 & 3.1 & 7 & +0.2 \\
\hline Lithuania & 44 & 3.6 & 1 & 41 & 3.7 & 1 & +0.1 \\
\hline
\end{tabular}

Source: WEF, The Global Competitiveness Reports 2013/2014 and 2017/2018 
Lithuania, Montenegro, Latvia and Poland are the best ranked among the analyzed countries according to the rank of the Innovation pillar in 2013/2014 (Table 3). A similar situation is in 2017/2018. The best ranked countries are: Lithuania, Poland, Bulgaria, and Latvia. The worst ranked country in 2013/2014 is Serbia, while the worst rank in 2017/2018 was recorded by Croatia. We also note that Latvia and Bulgaria achieved a significant positive change in the observed period. A decrease in the Innovation pillar in 2017/2018 compared to 2013/2014 are realized in Croatia, Montenegro, and Hungary (-0.2).

\subsubsection{Analysis of indicators of competitiveness of science in selected countries}

In order to provide a more relevant evaluation and more complete presentation of competitive advantages and disadvantages of the selected countries in the field of science, we will carry out a comparative analysis of the parameters of the observed countries in the field of science.

Table 4 Results of the WEF indicators in selected countries

\begin{tabular}{|c|c|c|c|c|c|c|c|c|c|}
\hline $\begin{array}{l}\text { Selected } \\
\text { sub indicators }\end{array}$ & 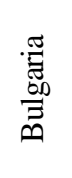 & 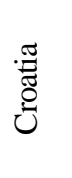 & 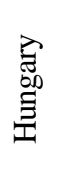 & 茎 & 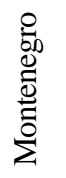 & $\begin{array}{l}\text { त्ञ } \\
\frac{\text { Oे }}{0}\end{array}$ & $\begin{array}{l}. \stackrel{\Xi}{\Xi} \\
\stackrel{\Xi}{\Xi} \\
\simeq\end{array}$ & 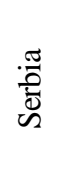 & 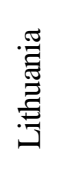 \\
\hline Hiring and firing practices & 67 & 131 & 27 & 91 & 73 & 97 & 51 & 80 & 111 \\
\hline Country capacity to retain talent & 119 & 131 & 126 & 118 & 100 & 89 & 132 & 134 & 109 \\
\hline Country capacity to attract talent & 118 & 135 & 112 & 122 & 107 & 113 & 131 & 132 & 117 \\
\hline Availability of latest technologies & 68 & 65 & 43 & 41 & 79 & 64 & 71 & 87 & 31 \\
\hline FDI and technology transfer & 47 & 111 & 48 & 80 & 72 & 37 & 86 & 101 & 32 \\
\hline Availability of scientists and engineers & 93 & 95 & 91 & 109 & 85 & 52 & 80 & 68 & 57 \\
\hline
\end{tabular}

Source: WEF, The Global Competitiveness Reports 2017/2018

The analysis of the data presented in Table 4 leads to the conclusion that Lithuania is best ranked according to the following parameters: availability of latest technologies and FDI and technology transfer. Hungary is the best country by the indicator hiring and firing practices. Poland has the best position among the analyzed countries according to country capacity to retain talent and availability of scientists and engineers.

Based on the data in Table 4, Serbia is best ranked according to availability of scientists and engineers and hiring and firing practices. Among the analyzed countries, Serbia is ranked as the worst according to the following indicators: capacity of the country to retain highly qualified personnel, capacity of the country to attract young talents and the foreign direct investment and technology transfer.

The biggest mistake of Serbia is that it allowed the outflow of highly educated and professional people, among which certainly there are those who possess exceptional skills, knowledge and abilities. The question that arises logically is: why do highly educated and professional individuals leave Serbia? 
Namely, the outflow from the country is generally influenced by two types of factors. Pull factors are factors that attract individuals to move to another country, and these are usually: high profits, better working conditions, greater career opportunities, and so on. Push factors are those that encourage individuals to leave the country. These are usually lack of prospects and the impossibility of professional development (Đorđević, 2016, 119).

\subsubsection{Analysis of the interdependence of the Innovation pillar and indicators of competitiveness of science}

In order to examine the interdependence of the Innovation pillar and the indicators of competitiveness of science in the observed countries, we use the standard multiple linear regression method based on the calculation of the coefficient of determination. The coefficient of determination shows the influence of the value of the observed indicators of competitiveness of science on the Innovation pillar.

The basic form of the regression model is (Green \& Salkind, 2014):

$$
Y=B_{1} X_{1}+B_{2} X_{2}+B_{0},
$$

where: $Y$ - dependent variable (the Innovation pillar (Inn)), $X_{1}, X_{2}$ - independent or explanatory variables, like: hiring and firing practices $(h f p)$, country capacity to retain talent (crt), availability of the latest technologies (alt), availability of scientists and engineers (ase), $B_{1}$ and $B_{2}$ are partial slopes for independent variables, a $B_{0}$ is an additional constant. Multiple linear regression shows which indicator of competitiveness of science in the model (a linear combination) better explains variations or changes in the results of the global innovation index (Pallant, 2011).

So, here we have: 1) one dependent quantitative variable - the index of global innovation or the Innovation pillar and 2) certain models or linear combinations of independent variables:

- Model $_{l}=$ Inn $_{l}=\mathrm{B}_{1} h f p+\mathrm{B}_{2} c r t+\mathrm{B}_{0}$.

- Model $_{2}=\operatorname{Inn}_{2}=\mathrm{B}_{1}$ alt $+\mathrm{B}_{2}$ ase $+\mathrm{B}_{0}$.

- Model $_{3}=I_{n} n_{3}=\mathrm{B}_{1} f t t+\mathrm{B}_{2}$ alt $+\mathrm{B}_{0}$.

- Model $_{4}=\operatorname{Inn}_{4}=\mathrm{B}_{1} h f p+\mathrm{B}_{2}$ alt $+\mathrm{B}_{0}$.

- Model $_{5}=\operatorname{Inn}_{5}=\mathrm{B}_{1} f t t+\mathrm{B}_{2} h p f+\mathrm{B}_{0}$.

- Model $_{6}=\operatorname{Inn}_{6}=\mathrm{B}_{1}$ alt $+\mathrm{B}_{2} c r t+\mathrm{B}_{0}$.

- Model $_{7}=\operatorname{Inn}_{7}=\mathrm{B}_{1}$ cat $+\mathrm{B}_{2}$ alt $+\mathrm{B}_{0}$.

- Model $_{8}=$ Inn $_{9}=\mathrm{B}_{1}$ ase $+\mathrm{B}_{2} f t t+\mathrm{B}_{0}$

- Model $_{9}=\operatorname{Inn}_{9}=\mathrm{B}_{1} f t+\mathrm{B}_{2} c r t+\mathrm{B}_{0}$

- Model $_{10}=\operatorname{Inn}_{10}=\mathrm{B}_{1} c r t+\mathrm{B}_{2}$ ase $+\mathrm{B}_{0}$

Table 5 shows the values of the Pearson coefficient of correlation between the independent variables in the analyzed models. On the basis of Table 5, we can conclude that the strongest link was realized within Model $_{9}$ or, more precisely, between FDI and technology transfer and country capacity to retrain talent. 
Table 5 Results of the correlation analysis of selected indicators of competitiveness (Pearson correlation coefficient)

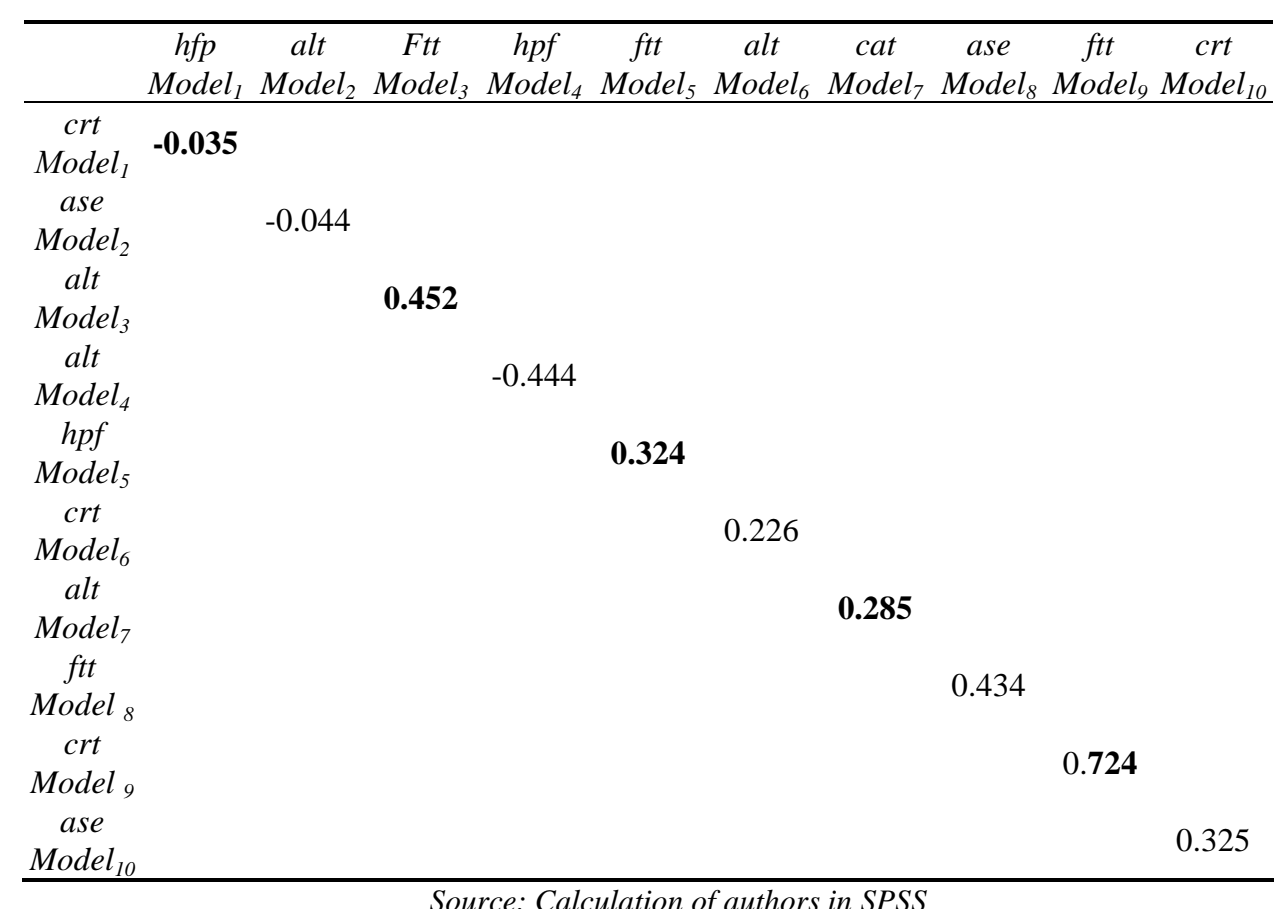

The results of the multiple regression analysis of the model are shown in column $R$ square in Table 6. The $R$ Square column is the coefficient of determination that shows how much of the percentage of changes in the results of the global innovation index is explained or caused by changes in the model's results.

Table 6 Statistical indicators of multiple correlation

\begin{tabular}{lccccccccccc}
\hline Models & Model $_{1}$ & Model $_{2}$ & Model $_{3}$ & Model $_{4}$ & Model $_{5}$ & Model $_{6}$ & Model $_{7}$ & Model $_{8}$ & Model $_{9}$ & Model $_{10}$ \\
\hline $\mathrm{B}_{1}$ & 0.137 & 0.538 & 0.287 & 0.146 & 0.443 & 0.487 & 0.473 & -0.236 & 0.498 & 0.294 \\
$\mathrm{~B}_{2}$ & 0.293 & 0.139 & 0.393 & 0.546 & 0.608 & 0.193 & 0.444 & 0.507 & -0.067 & -0.033 \\
$\mathrm{~B}_{0}$ & 2.096 & 0.213 & 0.132 & 0.118 & 1.330 & 0.155 & 0.069 & 1.978 & 1.836 & 0.514 \\
$\mathrm{R}^{2}$ & 0.329 & 0.676 & 0.841 & 0.743 & 0.562 & 0.765 & 0.892 & 0.606 & 0.568 & 0.254 \\
Adjusted R & 0.105 & 0.568 & 0.789 & 0.657 & 0.416 & 0.678 & 0.842 & 0.475 & 0.424 & 0.006 \\
Sig. & 0.302 & 0.034 & 0.004 & 0.017 & 0.084 & 0.013 & 0.002 & 0.051 & 0.081 & 0.415 \\
\hline \multicolumn{8}{c}{ Source: Calculation of authors in SPSS }
\end{tabular}

For example, the determination coefficient of $\mathrm{Model}_{3}$ is $78.9 \%$ (Table 6). This means that part of the changes in the results of the global innovation index, which appears 
because of its connection with the combination of independent quantitative variables FDI and technology transfer and availability of the latest technologies, is $79 \%$. The impressive degree of matching between $\mathrm{Model}_{3}$ and the Innovation pillar indicates that the relationship between this pillar, on the one hand, FDI and technology transfer and availability of the latest technologies, on the other, can be illustrated with linear function.

$$
\mathrm{Inn}_{3}=0.538 \mathrm{ftt}+0.139 \text { alt }+0.213
$$

where: $0.538-B_{1}, f t t$ - FDI and technology transfer, $0.139-B_{2}$, alt - availability of the latest technologies and 0.213 is $B_{0}$. The diagram of linear function shows more things (Figure 5).

First, the straight lines through the main bunch of points can be drawn, and another drawn line shows the trend upwards. Trend upwards indicates that this is the positive correlation that is the large values of the independent variables (FDI and technology transfer and availability of the latest technologies) correspond to the high values of the Innovation pillar (Figure 5).

The results of the regression analysis in Table 6 indicate that changes in values in

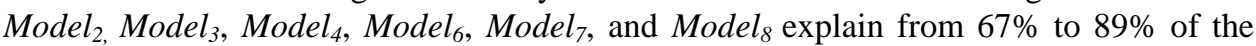
changes in the Innovation pillar and these results are statistically significant at the $5 \%$ significance level. Other regression models (Model, Model $_{5}$, Model $_{9}$, and Model ${ }_{10}$ ) are not statistically significant. Based on Table and Figure 5, we conclude that the results of multiple regression analysis confirm the hypothesis $\mathrm{H} 1$.

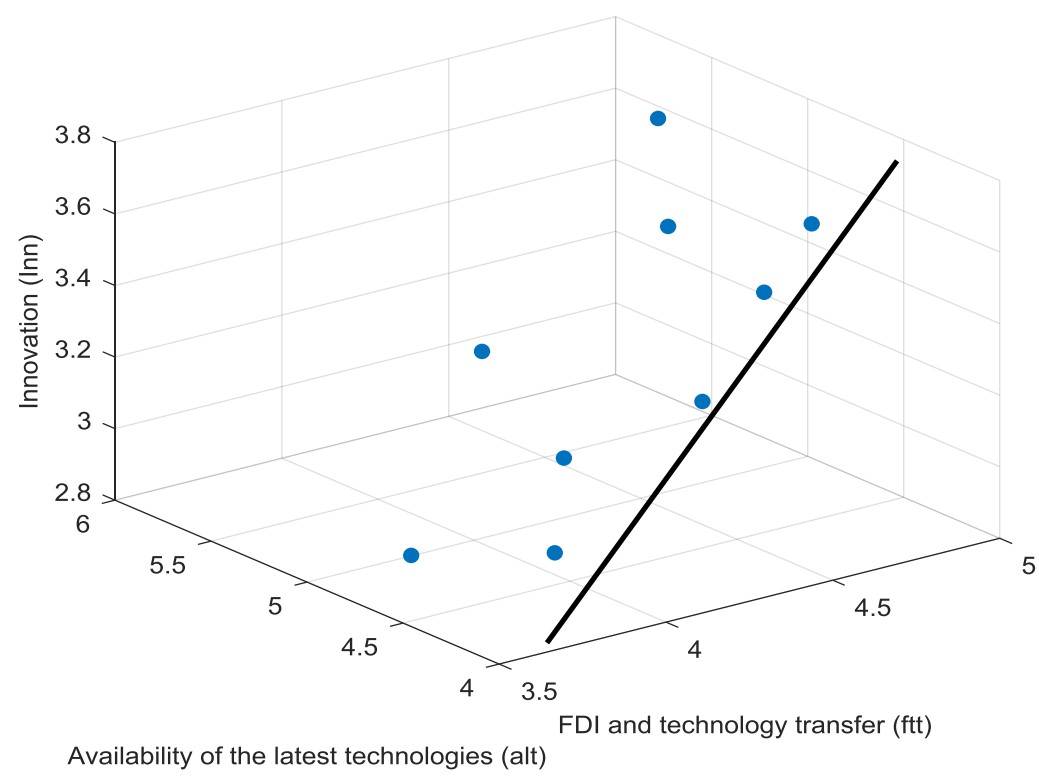

Fig. $5 \mathrm{Inn}_{3}=0.538 \mathrm{ftt}+0.139$ alt +0.213

Sources: $3 D$ Author's diagram in Matlab

Furthermore, the influence of individual independent variables in the observed models on the competitiveness of the state in the field of science, that is measured by the dynamics 
of the results of the Innovation pillar, is examined (Table 7). This allows us to answer the following question: which independent variable in a given model helps predict the value of the dependent variable to a higher degree? We will find the answer to this question in the Standardized Coefficients Beta column. For example, in Model $_{4}$, only the variable availability of the latest technologies (alt) has statistically significant value (Sig. $=0.007<0.05$ ). This means that only this variable is useful for predicting the results of the dependent variable.

The country capacity to retain talent, the country capacity to attract talent, the availability of the latest technologies and the foreign direct investment and technology transfer have a major impact on the ability of the selected countries to create competitiveness science (Table 7). There is significant need for regulation of these areas. Having in mind the data in Table 7, we conclude that the results of the extensive linear regression analysis confirm the hypothesis $\mathrm{H} 2$.

Table 7 Standardized share for each variable in the model

\begin{tabular}{|c|c|c|}
\hline Variables & Standardized Coefficients Beta & Sig. \\
\hline \multicolumn{3}{|l|}{ Model $_{1}$} \\
\hline$H f p$ & 0.275 & 0.443 \\
\hline Crt & 0.513 & 0.176 \\
\hline \multicolumn{3}{|l|}{$\mathrm{Model}_{2}$} \\
\hline Alt & 0.811 & 0.013 \\
\hline Ase & 0.138 & 0.138 \\
\hline \multicolumn{3}{|l|}{$\mathrm{Model}_{3}$} \\
\hline Ftt & 0.481 & 0.539 \\
\hline Alt & 0.038 & 0.017 \\
\hline \multicolumn{3}{|l|}{ Model $_{4}$} \\
\hline$H f p$ & 0.293 & 0.207 \\
\hline Alt & 0.823 & 0.007 \\
\hline \multicolumn{3}{|l|}{ Model $_{5}$} \\
\hline Ftt & 0.744 & 0.040 \\
\hline Hpf & 0.016 & 0.958 \\
\hline \multicolumn{3}{|l|}{ Model $_{6}$} \\
\hline Alt & 0.743 & 0.011 \\
\hline Crt & 0.338 & 0.147 \\
\hline \multicolumn{3}{|l|}{$\mathrm{Model}_{7}$} \\
\hline Cat & 0.495 & 0.015 \\
\hline Alt & 0.670 & 0.004 \\
\hline \multicolumn{3}{|l|}{ Model $_{8}$} \\
\hline Ase & -0.235 & 0.441 \\
\hline Ftt & 0.851 & 0.024 \\
\hline \multicolumn{3}{|l|}{ Model $_{9}$} \\
\hline Ftt & 0.836 & 0.082 \\
\hline Crt & -0.117 & 0.779 \\
\hline \multicolumn{3}{|l|}{ Model $_{10}$} \\
\hline Crt & 0.514 & 0.217 \\
\hline Ase & -0.033 & 0.933 \\
\hline
\end{tabular}

Source: Calculation of authors in SPSS 


\section{CONCLUSION}

In order to achieve a higher level of productivity in science, new activities are needed in terms of engaging in the necessary structural reforms and investments in order to improve productivity in the science sector, because only by raising the level of productivity of researches the sustainable growth of the society can be ensured in the long run.

Our recommendations for improving productivity of science in the analyzed countries are divided into 3 groups. The first group relates to the capacity of the state to employ young talents and retain good personnel in scientific activity. We propose designing an efficient and flexible system of material incentives that takes into account the complex, creative and intellectual nature of scientific activity. Policy makers should deal with the problem of low wages of researchers using the PRP schemes (performance-related pay schemes) (OECD, 2005). Also, the conclusion of employment contract for indefinite period according to the model of tenure track substantially removes the problem of highly educated and professional people leaving the country. We are committed to forming non-government funds that should be used to finance wages of the most productive researchers, as well as for other needs (procurement of materials, apparatus, samples, etc.).

The second set of proposals for increasing productivity in science in the analyzed countries relates to the improvement of technical infrastructure. The state should create the possibility that the creative spirit of domestic companies will revive by stimulating innovation through its procurement. An important recommendation to increase the competitiveness of science is to encourage multinational companies to invest in science, which should contribute to improving the technological capabilities of host countries, especially those lacking technological assets, knowledge and skills for dynamizing the tempo of economic growth (Schuch, 2014). The technology and innovative capacities, transferred through the investments of multinational companies, should enable the host country to organize the production of new products, to increase productivity and to develop new activities with high added value. Nonetheless, the research of knowledge transfers in the countries of Central Europe shows contradictory results (Biegelbauer et al., 2001). Although multinational companies in the 1990s invested in the science sector in the countries of Central Europe more than domestic companies, these investments did not significantly contribute to the development of research and development capacities. On the other hand, several scientific and technological projects carried out by multinational companies as a rule were not sufficiently connected with the local scientific database. One of the main reasons for this is the low level of development of human capital and the low level of infrastructure development in the host country.

The third group of measures to increase the productivity of research and researchers in selected countries relates to availability of scientists and engineers. If training cannot produce educated highly qualified staff of the world reputation in particular country, then it is necessary to seek support in foreign experience and resources (Medianik, 2017). In this case, an important role in improving the quality of human capital is the opening of departments of foreign universities in the observed countries. For the teaching activity, the best local and foreign experts will be engaged, and after the end of the training, students will receive two diplomas - diploma of foreign university and a degree from a joint university. It is also important to say that foreign universities such as Lomonosov, MIT, and Stanford are known for their natural and engineering sciences, and those areas of science are of strategic importance for analyzed countries from the point of view of building competitive economy. 
Acknowledgement: The paper is a part of the research done within the project 179066 funded by the Ministry of Education, Science and Technological Development of the Republic of Serbia.

\section{REFERENCES}

Altbach P., Reisberg L., Yudkevich M., Androushchak G. \& Pacheco I. (2012). Paying the Professoriate. A Global Comparison of Compensation and Contracts. New York: Routledge.

Auriol, L., Misu, M. \& Freeman R. (2013). Careers of Doctorate Holders: Analysis of Labour Market and Mobility Indicators. Paris: OECD Publishing.

Biegelbauer P., Griessler E. \& Leuthold M. (2001) The Impact of Foreign Direct Investment on the Knowledge Base of Central and Eastern European Countries. Reihe Politikwissenschaft 77. Vienna: Institute for Advanced Studies.

Bulgarian Ministry of Education and Science (2002). Attracting Young Scientists - Strategies against Brain Drain. Sofia: Bulgarian Ministry of Education and Science.

Đorđević, B. (2016). Ljudski resursi i njihovo upravljanje kao determinanta konkurentnosti preduzeća - stanje i perspektiva u preduzećima u Republici Srbiji [Human resources and their management as a determinant of competitiveness of enterprises - state and prospects in enterprises in the Republic of Serbia]. U: Krstic, B. (ed.). Ključni aspekti unapređenja konkurentnosti Republike Srbije (pp. 109-151). Niš: Ekonomski fakultet.

Gershman M. \& Kuznetsova T. (2013). Efficient Contracting in the R\&D Sector: Key Parameters. ForesightRussia, 7 (3), 26-36.

Gershman M. \& Kuznetsova T. (2011). Performance related Pay in the Russian R\&D Sector. Foresight-Russia, 8 (3), 58-69.

Gokhberg L., Zaichenko S., Kitova G. \& Kuznetsova T. (2011). Science Policy: A Global Context and Russian Practice. Moscow: HSE.

Green, S. \& Salkind, N. (2014). SPSS za Windows i Macintosh [SPSS for Windows and Macintosh], Beograd: Računarski fakultet.

Krstić, B. \& Stanišić, T. (2014). Impact of the technological readiness on competitiveness of the Balkan countries. In: Krstic, B. \& Darious, F. (Eds.). Determinants of improving the competitiveness of national economies and enterprises (pp. 85-102). Niš: Ekonomski fakultet.

Medianik, E. (2017). International Cooperation in Education - the Foundation for Future Wellbeing. International Organisations Research Journal, 12 (1), 7-22.

OECD (2005). Performance-related Pay Policies for Government Employees. Paris: OECD

OECD (2008). Tertiary Education for the Knowledge Society. Paris: OECD.

OECD (2010). Skills for Innovation and Research, OECD Innovation Strategy. Paris: OECD.

Pallant, J. (2011). SPSS: priručnik za preživljavanje: postupni vodič kroz analizu podataka pomoću SPSS-a [SPSS: Survival Guide: A step-by-step guide to analyzing data using SPSS]. Beograd: Mikro knjiga.

Porter, M.E. (2004). Building the Microeconomic Foundations of Prosperity: Findings from the Business Competitiveness Index. In WEF, M.E. Porter, K. Schwab, X. Sala-i-Martin, \& A. Lopez-Carlos (Eds.), The Global Competitiveness Report 2003-2004 (pp. 29-56). New York: Oxford University Press, Inc.

Schuch, K. (2014). Participation of the 'New' EU Member States in the European Research Programs - A Long Way to Go. Foresight-Russia, 8 (3), 6-17.

World Economic Forum. (2013, 2014, 2015, 2016, 2017). The Global Competitiveness Report. Geneva: World Economic Forum, Retrieved from: https://www.weforum.org/reports, Accessed on: 10 Nov 2018.

World Bank. (2014). World Development Indicators. New York: World Bank https://data.worldbank. org/indicator, Accessed on: 10 Nov 2018. 


\section{ZNAČAJ NAUKE ZA UNAPREĐENJE KONKURENTNOSTI NACIONALNE EKONOMIJE}

Cilj rada je da se ispita međuzavisnost analiziranih indikatora Svetskog ekonomskog foruma (SEF) i stuba Inovativnost koji se koristi kao pokazatelj konkurentnosti nauke. Ovaj odnos je analiziran u uzorku od 9 zemalja. U analizi su korišćeni raspoloživi izvori informacija o kategorijama koje su predmet opservacije. Ključni doprinos ovog rada sastoji se u pružanju jasnijeg uvida u faktore $u$ oblasti nauke koji smanjuju konkurentnost u odabranim zemalja i ukazivanju na prioritetne aktivnosti nadležnih državnih organa u cilju unapređenja i podizanja nivoa konkurentnosti nauke $i$ privrede. Rezultati istraživanja mogu da posluže kreatorima javnih politika u formiranju strategije $i$ politike unapređenja konkurentnosti i budućeg razvoja privrede u analiziranim zemljama.

Ključne reči: konkurentnost, nauka, mladi talenti, visoko-obrazovani stručnjaci, inovativnost 